\title{
Organisational and Individual Leadership Challenges During the Rescue Operation Following the 2004 Tsunami
}

\author{
Aida Alvinius, Erna Danielsson and Gerry Larsson
}

Additional information is available at the end of the chapter

http://dx.doi.org/10.5772/51140

\section{Introduction}

Disaster prevention and management involves both technical and social dimensions, implying that research inputs from both sides may provide important contributions. This chapter presents an attempt to develop a theoretical understanding of how Swedish response organisations managed the leadership challenges that they encountered during the rescue operation following the 2004 tsunami in South East Asia. Informants from three Swedish authorities, some at strategic level in Sweden and some at field level in Thailand, were interviewed while the rescue operation was still going on. Our text consequently examines their interaction and deals with the soft side of disaster management from a social science perspective.

The tsunami of 26 December 2004 had momentous consequences for large parts of Southeast Asia - from personal tragedies to far-reaching consequences for countries' economies and populations. In addition to Southeast Asia, the tsunami also affected many countries far from its epicentre. A recent analysis by the United Nations lists almost 250,000 dead people (http://www.who.int/hac/crises/international/asia_tsunami/en/). Of the European countries, Sweden suffered the greatest number of casualties in the tsunami. Some 20,000 Swedes were on holiday in Thailand when the tsunami struck. According to a Swedish Governmental Official Report (SOU, 2005:104), it could be confirmed in 2005 that 543 Swedes died and 18 are still missing (Alvinius, Danielsson \& Larsson, 2010a; Alvinius, Danielsson \& Larsson, 2010b).

\section{Our study - method}

\subsection{Selection of informants}

Following the guidelines of grounded theory (Glaser \& Strauss, 1967), the selection of participants was guided by a desire to find informants with a wide variety of experiences 
and occupational roles during the rescue operation. The organisations involved in this study are the Swedish Rescue Services Agency, the Swedish Armed Forces and the National Board of Health and Welfare in Sweden. Data were collected by interviews, following a prepared interview guide. During the tsunami in Southeast Asia in 2004, the task of the Swedish Rescue Services Agency was to lead and coordinate the operational work, i.e. the emergency team which was sent to Southeast Asia, and to manage logistics and home transportation of Swedish tourists who had suffered great losses in terms of both health and belongings. In accordance with Swedish law, the Swedish Armed Forces contributed personnel, equipment and transport to support organisations such as the Swedish Rescue Services Agency, the Swedish National Police Board and the Swedish Civil Aviation Administration. In this supporting role was the Swedish Armed Forces Operative Unit, which supervises missions in Sweden and abroad on a daily basis. The National Board of Health and Welfare was also involved during the rescue operation in Thailand, its task being to work with emergency management within the healthcare system, for example, with the prevention of infectious diseases, social services, provision of information and allocation of government grants to the county councils, home transport of injured Swedish tourists and provision of medical care in the field (Alvinius, Danielsson \& Larsson, 2010a).

\begin{tabular}{|c|c|c|c|}
\hline Organisation & $\begin{array}{l}\text { Number of } \\
\text { informants }\end{array}$ & $\begin{array}{c}\text { Female/ } \\
\text { Male }\end{array}$ & Their position (during the rescue operation) \\
\hline $\begin{array}{l}\text { 1. The Swedish } \\
\text { Rescue Services } \\
\text { Agency }\end{array}$ & 5 & $1 / 4$ & $\begin{array}{l}\text { - } \\
\text { - } \\
\text { - } \\
\text { An ead of Operational Management } \\
\text { Focal Point } \\
\text { - Two Crisis Managers }\end{array}$ \\
\hline $\begin{array}{l}\text { 2. Swedish } \\
\text { Armed Forces }\end{array}$ & 6 & $0 / 6$ & 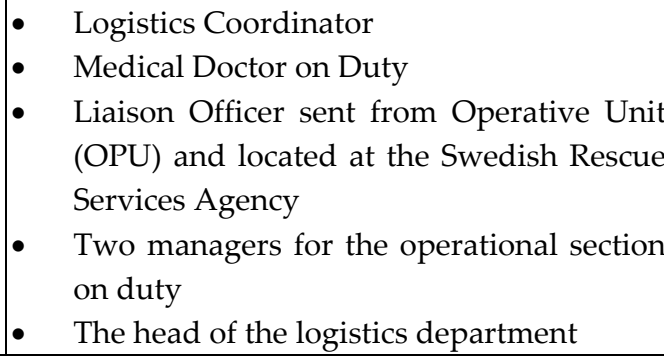 \\
\hline $\begin{array}{l}\text { 3. National } \\
\text { Board of Health } \\
\text { and Welfare }\end{array}$ & 6 & $2 / 4$ & $\begin{array}{ll}\text { - } & \text { Director-general } \\
\text { - } & \text { General Manager of Administration } \\
\text { - } & \text { Head of Social Services Department } \\
\text { - } & \text { Two Operativis Management Department } \\
\end{array}$ \\
\hline (N) informants & 17 & $3 / 14$ & \\
\hline
\end{tabular}

Table 1. Involved organisations, informants and their positions during the 2004 Tsunami 


\subsection{The formal structure of the Swedish rescue operation}

The political level consisted of the Ministry of Defence (heading the Swedish Rescue Services Agency, SRSA, and the Swedish Armed Forces), the Ministry of Health and Welfare (heading the National Board of Health and Welfare), the Ministry of Foreign Affairs and the Prime Minister's Office, directly subordinate to the Prime Minister. The formal structure of the rescue operation is shown in Figure 1.

\section{Political level \\ Central level of governmental organisations}

Field level operational command staff

Field level acting units

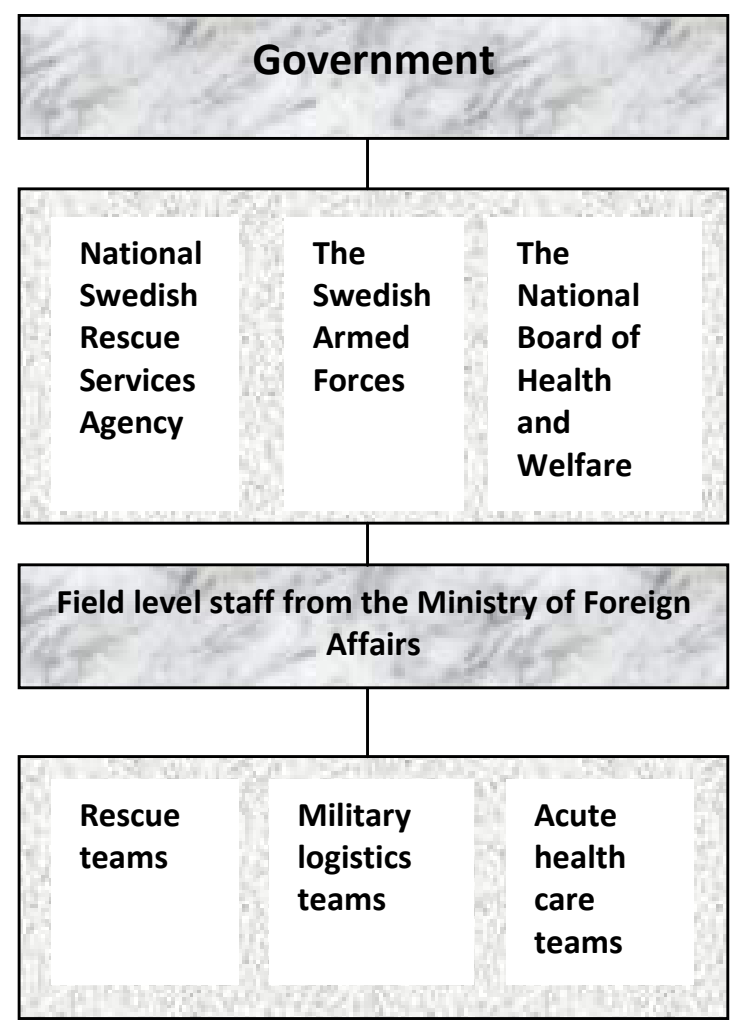

Figure 1. Formal structure of the Swedish rescue operation

This chapter focuses on leadership in the three aforementioned governmental agencies and their respective field teams, rather than on the political level. Each of those three organisations had headquarters in Sweden and the management of a rescue operation in the field in Thailand (see Figure 2). While a formal right of command existed within each organisation, there was no formal right of command for collaboration between them. The local operational command staff set up by the Ministry of Foreign Affairs mainly acted to assist coordination between the broader ranges of involved organisations. Leadership within and between organisations occurred directly (face-to-face) and indirectly (by subordinate leaders/managers). 


\begin{tabular}{|l|l|l|l|}
\hline Level/Organisation & $\begin{array}{l}\text { National Swedish } \\
\text { Rescue Services } \\
\text { Agency }\end{array}$ & $\begin{array}{l}\text { The Swedish Armed } \\
\text { Forces }\end{array}$ & $\begin{array}{l}\text { The National } \\
\text { Board of Health } \\
\text { and Welfare }\end{array}$ \\
\hline Central level in Sweden & &
\end{tabular}

Figure 2. Chain of command within the organisation and leadership through collaboration between organisations at central and field levels

\subsection{Outline of the chapter}

This chapter deals with the organizational and individual leadership challenges identified during the rescue operation. Firstly, we will describe the difficulties that bureaucratic response organizations need to manage when a disaster such as tsunami occurs. Secondly, we will describe individual aspects of leadership challenges which concern stress caused by disaster and emotion management. A number of illustrations will highlight both aspects.

\section{Organisational leadership challenges}

\subsection{Bureaucratic organizations and disaster management}

Swedish political leadership has received much criticism for its handling of Swedish citizens caught up in the tsunami. The main issue raised by an evaluation conducted by a parliamentary commission was that the Government did not have an efficient organisation for the management of a major disaster such as the tsunami. It was concluded that Sweden, in comparison to other countries, was characterised not only by the lack of an effective emergency organisation, but also by the lack of functional leadership at executive level (SOU, 2005:104).

This problem is not unique to the Swedish Government. Emergency response organisations usually face the challenge of having a bureaucratic structure characterised by precision, discipline, reliability and predictability on the one hand (Andrzejewski, 1954), and the demands of meeting extreme situations where predefined directives and routines simply cannot cover all possibly emerging contingencies on the other (Ben Ari, 2005; Kapucu, 2006). The greater the uncertainty, the more difficult it is to routinize activity by preplanning (Morgan, 1986). The very structure of bureaucratic response organisations tends to stifle the creativity and flexibility required to manage large-scale disasters (Kendra \& Wachtendorf, 2003). Some of the inadequacies tend to be intra-organisational. Performance may be confounded by a set of built-in conflicts that severely constrain policy-making, internal 
activities and actual operations. Typical clashes are based on irrational considerations such as internal departmental competition, political rivalries, jealousies, and interests. These built-in conflicts in bureaucratic organisations hinder collaboration, coordination and optimal use of resources (Kirschenbaum, 2004; Drabek \& McEntire, 2002).

Rescue operations performed in foreign countries constitute a special case. In domestic disasters, rescue teams typically arrive at the site first and higher management staffs are built up successively. When a disaster takes place abroad, however, a different sequence typically occurs. Firstly, there has to be acceptance on a political level. Secondly, orders are given to the central governmental agencies, and thirdly the field teams can deploy. For this kind of rescue operation, which primarily aims to assist people from one's own country rather than the local population, research in regard to strategic and operational leadership is lacking. When rescue organisations take on an assignment, they constantly deploy and redeploy in partly new forms that need to function each time a disaster occurs. Studying a special case like the Tsunami can therefore add value to the broader picture of disaster management, which is important since large-scale disasters today are often handled by a cooperation of emergency rescue units from all over the world.

\subsection{Improvisation and constraints of managing disaster}

The complexity of crisis management has been highlighted in previous research. Drabek $(1983,1985)$ showed that disaster management should be capable of responding to episodic and very temporary change. These kinds of episodic, extreme events create the need for both planned and improvised collaboration and cooperation. Mendonça and Wallace (2004) pointed out that insight into how organisational context may shape improvisation, coordination and collaborative response activities is needed both within and between organisations because response activities can be expected to range from planned to improvised. They emphasise the importance of improvisation during the response phase and suggest a plan that would lead to increased understanding of how improvisation as a response to extreme events may be observed and supported. As Kendra and Wachtendorf (2006, p. 29) state, "Improvisation is required to connect that which is understood retrospectively and that which is emerging." Uhr et al. (2008) used social network as a method of analysing an emergency response system in order to identify people who served as links between two response organisations in the field. They observed the value of this function, which, in organisational theoretical terms, could be labelled 'boundary spanners' (Williams, 2002; Uhr et al., 2008). Other studies call for vertical and horizontal improvements in communication across various levels of government (May, 1985). McEntire (1998) notes that coordination will be increasingly relevant in disaster response operations when there have been some sort of pre-disaster ties between the agencies involved. These ties help generate familiarity with one another and help develop norms that emphasise collaboration. They generate a willingness to work with others to meet the needs of relief recipients and help create a network or means within which information regarding a disaster situation can be easily shared and quickly transmitted to others. Thus, a key to 
effective collaboration appears to be the interaction and coordination of response organisations with each other before a disaster strikes (Auf der Heide, 1989; Drabek \& McEntire, 2002).

Our study was conducted before the Swedish Governmental Official Report was released. We discovered that many high-level leaders in Swedish Government were on Christmas vacation when the tsunami struck South East Asia in 2004, and even the prime minister was away and had not watched the news. However, for some other organizations that are not normally operational during vacations, the holiday was actually advantageous as it meant that day-to-day work did not hinder disaster management activities (Alvinius, Danielsson \& Larsson, 2010a).

But it was both when the actual organisation wasn't working, or rather, it wasn't active because there were a lot of public holidays and I'd say that was perhaps an advantage in this context because the capacity was there for it. There weren't that many other activities requiring immediate attention so we didn't need to put anything to one side because we could just do that. /.../. But if it had been high season, like, with meetings from morning to night, the situation would have been really stressful because you would have been, you would have been forced to organise yourself differently.

Nevertheless, there were many situational constraints hindering leadership performance and causing stress, for example, infrastructural/environmental aspects such as lack of resources, the impediment of routines and day-to-day activities, media as an external stressor, delays, time differences and understaffing.

Asserting individual and organisational boundaries hampered successful collaboration in some cases. Territorial thinking came into play between authorities both during and after the disaster initiative and was accentuated in subsequent discussions once normalcy had gradually crept back into the authorities' day-to-day activities. A shortage of computers and mobile phones was another obstacle to overcome. Staff in Sweden quickly made provision for the necessary equipment to be sent over to the field staff in Thailand, thus establishing communication between command centre and the field, but the geographical distance between the two countries meant there was a six-hour time difference. When field staff in Thailand needed extra resources it could mean staff back in Sweden had to work at 3 am. According to one informant, this time difference was seen to be an obstacle:

So it has involved an adjustment, a time adjustment - there's six hours difference between us and Thailand, which means they're up and about over there at $3 \mathrm{am}$.

Understaffing at Bangkok airport made it more difficult to redeem materials sent over from Sweden. The need for more staff at the airport was evident:

There have been a few problems with other organisations only sending things over to a large airport like Bangkok, without a recipient. That makes it really difficult to find the stuff and you have to be careful about transport documentation and things like that, and communication. 
Leadership at the highest organizational level in Sweden geared up too slowly to the extreme situation that prevailed following the tsunami, sending a rescue team to Thailand a couple of days after its occurrence. Nevertheless, when news of the disaster broke, activities began which could be described as expectancy-based preparations. These were partly performed according to general and established plans (structure), and were partly innovative because of the novelty of the situation (allowing freedom of action). Within hours, frustrations began to surface due to rigidity and lack of decision-making at governmental level, thus delaying the rescue operation. However, once the decision to go ahead with the operation had finally been made, government sentiment now swung towards granting a high degree of latitude in its set-up. When the field groups arrived in Thailand, the initially chaotic situation gradually became more ordered, and leadership at central level in Sweden successively became more routine-based (structure). The present case shows that managing contradictory needs for structure and freedom of action becomes easier when link functions and roles (known as boundary spanners) arise in the formal hierarchy during an emergency situation.

However, there were differences in the need for structure and freedom between the two operational levels. For central level staff in Sweden, structure was important because their tasks revolved around obtaining mandates, leaders at this level thus having to wait for the green light from the relevant political authority in order to act. For workers in the field, the opposite was true, as there the task involved reacting to what had happened. In time, however, the needs of the field came closer to that of central level, and after a while both had established structures.
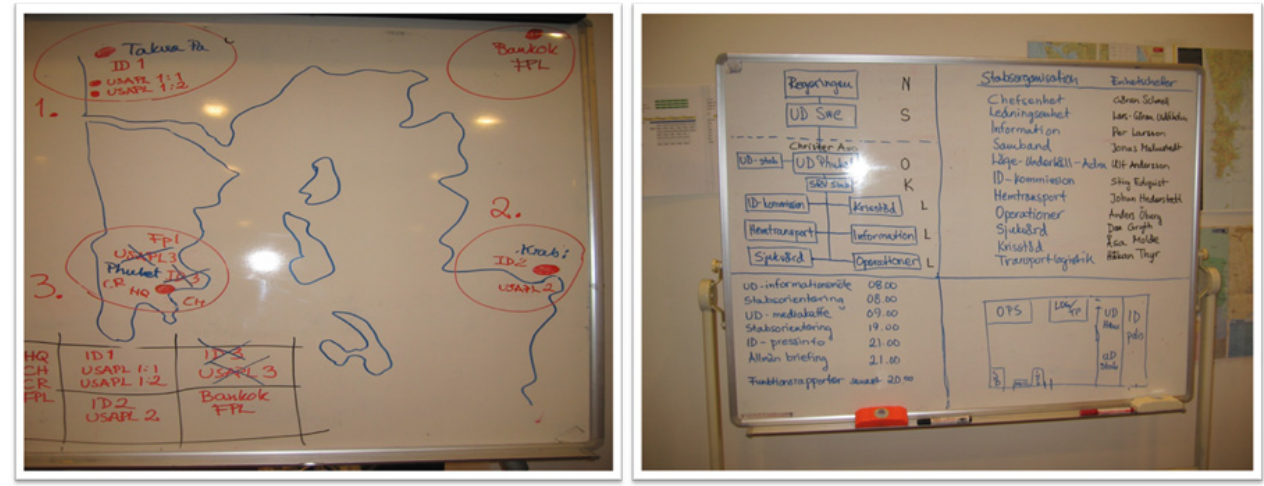

Picture 1. "Field level managing chaos and building gradually more ordered situation". Photo: Torbjörn Olsson

The ability to act and deal with the chaotic situation on the ground was a necessity for field workers in Thailand as Swedish routines did not work and situations had to be dealt with then and there. We illustrate:

But with so few people you can't sacrifice the rescue part in favour of establishing structure - that has to come afterwards. 
On the one hand, a free rein was needed and a lot of the work was dealt with ad hoc. But on the other hand there was a need for fixed structures.

Routines were an expression of the existence of structure and of its necessity in order for the authorities to act. This manifested itself as a need to follow line organisation and to stay within individual parameters of operation. Decisions had to come from higher authorities there was a great need to have someone with the courage to 'push the button'. For the work to be carried out there was also a desire to have support staff who could help with everything from making coffee and fetching food, to answering calls from volunteers.

As stated, however, the desire for a free rein was just as apparent as the desire for routines. Making decisions was important, and it was better to make one too many than one too few, as illustrated by utterances such as 'no rules - do it!', 'make a fast decision', informally 'make it right later', 'no limitations'. According to one of the informants, acting without limitations was characteristic of workers on the ground in Thailand:

You have to decide quickly, you have to - how should I put it... you can't wait any longer.

So I'd rather make one decision too many than one too few. I think it's really important - especially in situations where you can't wait and have to have the courage to make a decision.

One informant in the field felt that flexibility was a desirable quality in new collaborators, as work structured around a checklist would be perceived as hampering an initiative. In a demanding situation, imagination combined with flexibility was what was necessary out in the field, and to achieve this, mentors were needed to teach less experienced staff to act accordingly. The informant maintained that checklists were not helpful:

I've had dealings with a lot of young guys who are going to be commanding officers and they want a checklist. You're not getting one, I say; you'll have mentors and you'll be taught this way and from experience etc - that will give you know-how.

\subsection{Boundary spanners as facilitators between leaders}

When link functions and roles arose in the formal hierarchy, the process of managing contradictory needs for structure and freedom of action became easier for higher levels of leadership. These links were individuals with specific competencies facilitating collaboration and communication within and between organisations. Webb (1991) refers to individuals with these kinds of competencies as boundary spanners. By providing linkages which do not exist on organisational charts, boundary spanners facilitate the sharing and exchange of information and link their organization with the external environment, especially in time of crisis (Aldrich \& Herker, 1977; Alvinius, Danielsson \& Larsson, 2010b).

As mentioned earlier, there is a need for improvisation in disaster management from an organisational and leadership perspective. Organisational management of environmental demands such as geographical distance, multinational collaboration with different actors 
such as Non Governmental Organisations (NGO), building a common operating picture and situational awareness on site, requires management of those difficulties, sometimes at the same time (Alvinius, Danielsson \& Larsson, 2007). One way to overcome differences between an organisation and its environment is to use boundary spanners. These functions have been shown to be essential to the efficient and effective operation of organisations by improving communication and collaboration between groups (Aldrich \& Herker, 1977; Williams, 2002; Alvinius, Danielsson \& Larsson, 2010b). We conclude that during the 2004 tsunami, links or boundary spanners contributed greatly to mitigating the difficult circumstances encountered by the Swedish disaster initiative in terms of overcoming great geographical distance and delayed communication between the central and field levels, and in dealing with the scope of disaster and lack of disaster experience among Swedish leaders.

Two kinds of links were identified in our study, labelled planned and spontaneous links respectively. These links connect organisations and individuals both vertically and horizontally; acting vertically between various hierarchical levels within an organisation or between the management of the authorities and the political level, and horizontally between different organisations, or between individuals at the same level within the same organisation/agency (see Table 2).

\begin{tabular}{|c|c|}
\hline \multicolumn{2}{|c|}{ Link } \\
\hline Planned Links & Spontaneous Links \\
\hline $\begin{array}{l}\text { Predefined position and task } \\
\text { a) Liaison officer } \\
\text { b) Representative role } \\
\text { c) Coordinator } \\
\text { d) Negotiator } \\
\text { e) Information officer } \\
\text { f) Observer } \\
\text { g) Translator (organisational differences) }\end{array}$ & $\begin{array}{ll}\text { No predefined position and task } \\
\text { - } & \text { May belong to another organization } \\
\text { - } & \text { Appears on site/field } \\
\text { - } & \text { Coordiaboration } \\
\text { - } & \text { Support } \\
\text { Purposes } \\
\text { - } & \text { Getting the picture on site } \\
\text { - } & \text { Sense-making } \\
\text { - } & \text { Estimating the allocation of resources on } \\
\text { site } & \text { Other competencies, such as translation } \\
& \text { of another language }\end{array}$ \\
\hline $\begin{array}{l}\text { Aspects of trust } \\
\text { Network of contacts } \\
\text { Organisational acceptance, trust is related to } \\
\text { a position not only to individuals }\end{array}$ & $\begin{array}{l}\text { Aspects of trust } \\
\text { Swift trust } \\
\text { Willingness to work across organisational } \\
\text { boundaries depends on organisational } \\
\text { reputation }\end{array}$ \\
\hline $\begin{array}{l}\text { Negative aspect of Planned Links } \\
\text { Too many links mean too many different } \\
\text { apprehensions }\end{array}$ & $\begin{array}{l}\text { Negative aspect of Spontaneous Links } \\
\text { Running the risk of being rejected }\end{array}$ \\
\hline
\end{tabular}

Table 2. Illustrates major characteristics of Planned and Spontaneous Links 
A planned link is related to an individual's organisational role and is most often approved and accepted by superiors. Planned links refer to individuals with collaboration tasks within their responsibility and mandate, such as liaison officers or negotiators. This linking function may have appeared successful in a previous event, which led to the establishment of this kind of link in the organisation. Planned links may be decision-makers who are able to act outside the framework of the organisation because he or she possesses organisational acceptance and has a wide experience of managing disasters or unexpected events. Individuals with planned link functions in crisis situations belong to the ordinary chain of command during ordinary day-to-day work and may have a managerial position during ordinary working conditions.

Spontaneous links appear to arise when required by the extreme situation. This could happen when areas of responsibility, authority, competences, experiences and resources fail. Spontaneous links often emerge in the field and enjoy the immediate trust of people close by, for example planned links. They are not affiliated with an organisation but they are ordinary people willing to volunteer their special competencies to help during a rescue operation. Spontaneous links have competencies that are different to that of planned links and their existence is temporary. A typical spontaneous link may be a volunteer language translator during a disaster. To make the collaboration process possible, spontaneous links rapidly need to gain trust, but they also run the risk of being rejected if they are not part of an involved organisation. The need for spontaneous links disappears when the crisis is over.

During the tsunami rescue operation a liaison officer, a planned link, was a previously appointed person whose job was to facilitate cooperation between organisations, to liaise between organisational cultures and to make collaboration more efficient, resulting in time savings. The Swedish Armed Forces have a built-in structure for this, which is illustrated in the following quote from a centrally-placed manager of the Swedish Rescue Services Agency:

Initially, the Swedish Armed Forces had a liaison officer who knew the military language and system placed among the Rescue Services staff. I had discussions with the liaison officer there, and he was familiar with our stuff.

An excerpt from the interview with the liaison officer mentioned in the above quote:

What I'm most satisfied with is having been able to create the contacts, so the Rescue Services personnel and the Armed Forces personnel had a common entry point, and that was me. So I had a lot of discretion and saved the individual administrators a lot of time.

Spontaneous links happen to be the right individuals in the right place when an unexpected event occurs, which is often experienced by the informants as positive. Strenuous situations and demands can lead to spontaneous links emerging. Actors appear when a need becomes visible, as was the case after the tsunami: 
At the end of the day I got in touch with a guy who was in contact with someone down there (Thailand); he suddenly appeared - this Swedish Air Force officer who was there celebrating his 50th birthday. So he turned up and asked if they needed help with anything.

\section{Individual leadership challenges}

\subsection{Stressors and stress reactions}

Individual leadership challenges varied according to whether or not the leaders were at home in Sweden or on the ground in Thailand. In the initial phase of the tsunami disaster, uncertainty among the Swedish authorities reigned and there was no understanding of the consequences the Southeast Asian disaster could have for Swedish society. Our informants exhibited stress reactions due to lack of control, for example, they found it difficult to predict what measures needed to be taken. The informants also testified to feeling powerless, for example, in the absence of written directives from higher authorities. Such absence of directives necessitated increased financial responsibility and flexibility, according to several interviewees. Alongside the other causes of stress, the absence of orders led to increased stress among command staff, as illustrated by the following comment:

It can be stressful to make a decision to send over several million kronor's worth of containers, buy air services from an aviation broker and then fly over the containers - being sure that in the end, it won't be me personally paying this 10000000 (about one million Euros).

The tsunami catastrophe took its share of Swedish victims, among them parents, leading to a dilemma for the National Board of Health and Welfare in terms of how to manage children who had been orphaned in connection with the disaster. To illustrate:

One of the first questions raised was, what provision was there for taking care of children who had lost their parents - how would it be handled?... and someone got that question from abroad, about what guidelines the National Board of Health and Welfare had.

Stress resulting from media pressure is described in the quote below:

There was probably a whole bloody shed-load of them ringing, and so it started, the papers and press calling and they push like there's no tomorrow.

Typical reactions ignited by these stress factors included a sense of uncertainty about how to act, uncertainty as to the consequences for one's self and others, and frustration. However, many of those who were involved in the disaster effort but working from their usual workplaces in Sweden described these stress reactions as mild:

It's not a big problem. You shouldn't attach any importance to it. No! It's not a war situation, there's no stress /.../ Daylight, no-one shooting at me, the lights are on. Sweden's in one piece, I go home, talk to my wife: a few odd conversations but no, not so very stressful. 




Picture 2. "Deceased Swedes prior to the first air transport back home. Staff on the ground had the job of collecting the deceased from refrigerated containers and placing them in coffins prior to transporting them home. The coffins were to be draped with the Swedish flag before departure and everything was to be managed with dignity, staff having discussed how to address relatives on the scene at the airport. The first six coffins were then transported to the Uppsala garrison for a memorial service at which the deceased were passed on to their families. Having to put the deceased in coffins and meet their relatives was an emotionally trying task for the staff." Photo: Torbjörn Olsson

Nevertheless, on the ground in Southeast Asia, stress reaction levels were significantly higher. Typical stressors for fieldworkers were their own organisation's lack of understanding at central level as to the tasks they were solving, as well as deficiencies in their own understanding as to the role their organisation was playing and how they should be employed in operations. Reactions such as disappointment were a fact when central level conveyed criticism instead of making concrete decisions:

They were aware that we were coming - a group like us - but they didn't initially fully comprehend the capacity we had and how we were to be employed and such.

In the field, staff was affected by physical symptoms such as sleep deficit and psychological conditions such as tunnel vision. In some cases, the number of tasks was perceived to be burdensome since they were being carried out under difficult conditions. Intense work shifts and sleeplessness wore out the fieldworkers, even though they were willing and committed to helping.

I was working with great focus and intensity, most likely had tunnel vision to a degree, worked too much /.../ During those days I was working, calculated it was 96 hours /.../ I was most stressed by the fact that I slept too little so to speak. 
The character and extent of the tsunami catastrophe was perceived to have caused high levels of stress and subsequent stress reactions. Many of the fieldworkers testify to having strong feelings:

So there's like, about 10,000 to 15,000 dead people over there and you see all the destruction /.../ Perhaps you can associate stress with the fact that sometimes, when you've been meeting with a lot of relatives, sometimes for a whole day, when we went out with them and stuff so you got so close to them. You got told so much that you got really affected, you know. We cried several times. We could have parting ceremonies with coffins and flags; we could have four to five a week.

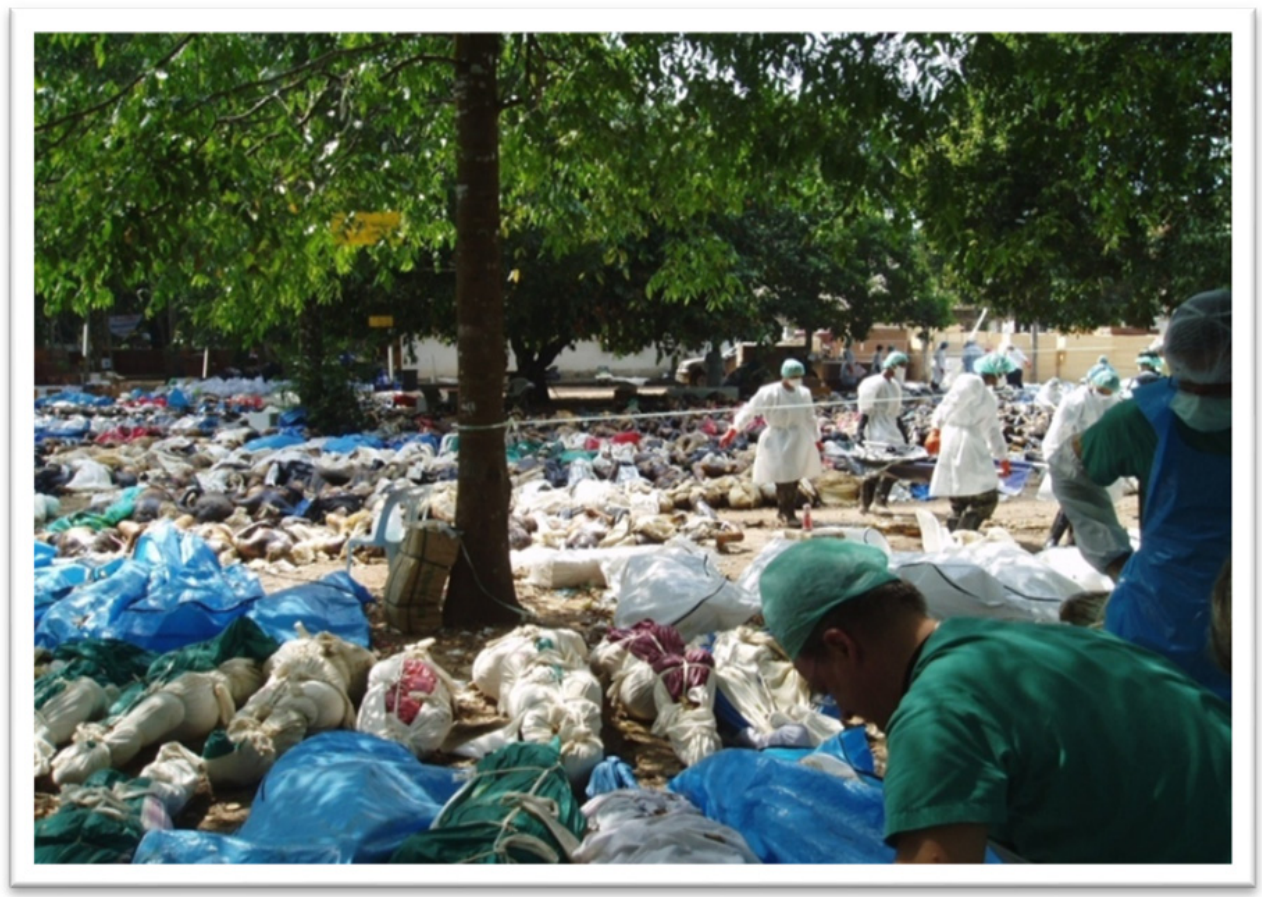

Picture 3. Collection point for the dead in Ban Muang. Staffs were confronted with an unfathomable number of dead people there and it was difficult to take in. At the same time, conditions were static - the people were already dead. The task now was to identify them as carefully and as sensitively as possible. Not much more could be done than to play one's part as well as possible. Photo: Torbjörn Olsson

As previously mentioned, field workers were committed and willing. They wanted to do a good job and be professional but stretched themselves in the process:

The commitment was there, and the willingness was there in the whole team to do a professional job and do it well. So I think that was different from the others back in Sweden but on the other hand we really stretched ourselves. 
In summary (see Table 3), the factors that triggered stress reactions at central levels of authority in Sweden were a lack of directives, the need to make serious decisions without formal mandates, pressure from the media, and new, unexpected questions and demands from one's own organisation. Factors triggering stress in the field were associated more with central level's lack of understanding for or knowledge of what fieldworkers were doing there and of the competence they possessed, the intense work pace and length of the working day, and the experience of encountering relatives and the deceased at parting ceremonies.

\begin{tabular}{|c|c|c|c|}
\hline $\begin{array}{l}\text { Stressors, stress } \\
\text { reactions and } \\
\text { emotional } \\
\text { management }\end{array}$ & Stressors & Stress reactions & Emotional management \\
\hline $\begin{array}{l}\text { Central level in } \\
\text { Sweden }\end{array}$ & $\begin{array}{l}\text { - Lack of control } \\
\text { and formal } \\
\text { mandate } \\
\text { - Financial } \\
\text { responsibility } \\
\text { - Orphaned } \\
\text { children } \\
\text { - Media pressure }\end{array}$ & $\begin{array}{l}\text { - Mild stress } \\
\text { reaction } \\
\text { - Powerlessness } \\
\text { - Frustration } \\
\text { - Sense of } \\
\text { uncertainty }\end{array}$ & $\begin{array}{l}\text { - Distance from the field } \\
\text { prevent strong emotions } \\
\text { - Mobilise right resources } \\
\text { - Emotional management } \\
\text { at the macro-level } \\
\text { (Sweden is in sorrow) } \\
\text { - Using previous } \\
\text { experience and personal } \\
\text { networks }\end{array}$ \\
\hline $\begin{array}{l}\text { Field level in } \\
\text { Thailand }\end{array}$ & $\begin{array}{l}\text { - Lack of under- } \\
\text { standing at the } \\
\text { central level } \\
\text { - Rescue actions } \\
\text { and number of } \\
\text { tasks } \\
\text { - Difficult } \\
\text { conditions such } \\
\text { as climate and } \\
\text { dead bodies }\end{array}$ & $\begin{array}{l}\text { - Increasing stress } \\
\text { reaction } \\
\text { - Sleep deficit } \\
\text { - Tunnel vision } \\
\text { - Disappointment } \\
\text { - Sadness } \\
\text { - Pride } \\
\text { - Willing and } \\
\text { committed to } \\
\text { helping }\end{array}$ & $\begin{array}{l}\text { - Sharing strong emotions } \\
\text { at the field } \\
\text { - Managing own and } \\
\text { others emotional } \\
\text { reactions. Pointing out } \\
\text { if a colleague is too } \\
\text { stressed. } \\
\text { - Using previous } \\
\text { experience and personal } \\
\text { networks } \\
\text { - Effective leadership and } \\
\text { cultural awareness }\end{array}$ \\
\hline
\end{tabular}

Table 3. Stress and stress reactions among leaders at the central level in Sweden and the field level in Thailand

\subsection{Emotional management}

Stressful events like the tsunami impact greatly on both individuals and organisations. Crisis management organisations should be able to adapt rapidly to the pressures 
emanating from the surrounding environment, i.e. the world outside the parameters of the organisation. Society puts demands on authorities to manage crises that arise, and these demands can trigger emotional processes on an individual, group and organisational basis. Such demands are often about mobilising the right resources in relation to the occurred event, and it is in this context that one often talks about incremental stress and tension (Alvinius, Danielsson \& Larsson, 2010a).

Recently, researchers have become increasingly interested in examining the subject of emotions in day to day activities, but also in stressful, life and death situations (Alvinius, Kylin, Starrin \& Larsson, 2011). From a societal perspective, there are emotional cultures which must be followed, involving compliance with other people's expectations of emotional expression. To meet these expectations, the individual must subscribe to a certain amount of emotion management. One likely significant aspect of the work carried out by operations staff during the tsunami catastrophe was the management of their own as well as others' emotional reactions. Related research from sociology has elicited the concept of 'emotional labour' (Hochschild, 2003), in which the conclusion is made that service professions (as opposed to manufacturing ones) are subject to the demands of prescribed emotional expression, which more or less requires individuals to modify their own natural feelings. They are expected to outwardly exhibit a certain 'face': a composite of a particular vocabulary, tone, body language, dress etc.

Some examples of emotion management during the tsunami rescue operation are mentioned in the following. Each decision-maker and collaborator serving during the tsunami disaster brought their own experiences and contacts to operations. Previous experience was in their bones, allowing them to act directly. Other informants made mention of their own special experiences, for example, from Africa, where they were used to international aid initiatives, medical care and working under time-critical conditions. This type of experience was an asset to those going on to manage their own emotions during the tsunami disaster rescue operation.

Thus, previous experience of managing international crises was also an asset to individuals and organisations, as testified to below:

I think a lot of this commitment exists in the Civil Contingencies Agency - has done historically, so to speak /.../ because we've carried out international aid operations.

However, the experiences from the tsunami disaster were, according to our informants, of a completely new kind and described as once-in-a-lifetime occurrence; they had never before encountered this kind of catastrophe in their careers. The fact that so many of the afflicted were Swedes and spoke their native language brought the field workers closer to the victims and more involved in their destinies. Managing the tsunami catastrophe required dealing with a number of emotions such as grief, sadness, anger, joy and pride. Familiarity with individuals and personal networks readily facilitated this emotion management. More generally, it was found that effective leadership was related to effective emotion management. This, in turn, was related to cultural awareness in addition to effective personal emotion-focused coping techniques. 


\section{Conclusions}

The act of maintaining balance between authority and structure on one hand and allowing freedom of initiative on the other was found to be the most significant aspect of leadership during the tsunami rescue operation. Thus it can be concluded that operational managers at faraway disaster sites should be prepared to act independently without higher command. When there is distance and information asymmetry between central strategic leadership and the field, operational commanders need to operate autonomously in order to be effective. The functional aspect of putting the formal chain of command aside and taking personal initiative at lower levels also has theoretical implications. According to most organisational theories (e.g. Cameron et al., 1987), top management tends to take a firmer grip in tough times. Decision-making responsibility is passed upwards, participation decreases and control is emphasised. The present study, just like a military study (Larsson et al., 2007), shows cases where the opposite was functional. We think this is of value in highlighting the importance of flexibility and freedom of decision-making at the initial stage of any disaster, at which point decentralisation should be encouraged.

A second major finding is the identification of planned and spontaneous links, and the different positions that these links can take. They contribute in diverse ways to effective operation by enabling exchange between individuals and groups. When functioning at their best, these links provide the rigid structure of bureaucratically organised emergency response agencies, with the creativity and flexibility required. In short, the two kinds of links contribute to organisational adaptation to environmental conditions. We propose and encourage openness towards spontaneous links and paying increased attention to trust, for instance in selection and organisation development processes. The following specific implication is also suggested: educate organisational gate keepers and boundary spanners acting as planned links in order to avoid an over-emphasis on control-driven compliance. This is a long-term endeavour and points to the importance of organisational climate.

The third major finding is the demonstration of the importance of a so far underestimated operational skill, the ability to manage one's own and others' emotions. Our study shows that leaders utilise various ways of emotional management in order to fulfil the demands partly laid upon them by the disaster environment and partly by their own bureaucratic organisation. The extreme demands of a disaster rescue operation highlight the need to look beyond the purely rationalistic perspective of emergency response organizations. Operational effectiveness is also dependent on the quality of the key actors' emotional labour and emotions-focused coping skills capacity.

\begin{tabular}{|c|c|}
\hline $\begin{array}{c}\text { Leadership challenges } \\
\text { at central level in Sweden }\end{array}$ & $\begin{array}{c}\text { Leadership challenges } \\
\text { at field level in Thailand }\end{array}$ \\
\hline Need for structure & Need for freedom of action \\
\hline Planned Links facilitate collaboration & $\begin{array}{c}\text { Planned Links facilitate collaboration } \\
\text { Spontaneous Links are recognised }\end{array}$ \\
\hline Manage one's own emotions & Manage one's own and others' emotions \\
\hline
\end{tabular}

Table 4. Illustrates main conclusions 
The generalizability of the three presented conclusions is, strictly speaking, an empirical question. Thus, we encourage research colleagues to consider and evaluate them in future disaster studies.

\section{Author details}

Aida Alvinius, Erna Danielsson and Gerry Larsson

Swedish National Defence College and Mid Sweden University, Sweden

\section{References}

Aldrich, H. \& Herker, D. (1977). Boundary-spanning roles and organization structure, Academy of Management Review, Vol. 2, pp. 217-230, ISSN 03637425

Alvinius, A., Danielsson, E., Kylin, C., \& Larsson, G. (2007). Lika lägesbild, olika situationsförståelse, ILM: Serie I:34, ISBN 1401-5676, National Defence College, Department of Leadership and Management, Karlstad, Sweden

Alvinius, A., Danielsson, E., \& Larsson, G. (2010a). Structure versus freedom of action: leadership during the rescue operation following the 2004 tsunami, International Journal of Emergency Management, Vol. 7, Nr. 3/4, pp. 304-322

Alvinius, A., Danielsson, E., \& Larsson, G. (2010b). The inadequacy of an ordinary organisation: Organisational adaptation to crisis through Planned and Spontaneous links, International Journal of Organisational Behaviour, Vol. 15, pp. 87-102, ISSN 1440-5377

Alvinius, A., Kylin, C., Starrin, B., \& Larsson, G. (2011). Rules of Emotional Engagement: samverkan och förtroendeskapande ur ett emotionsteoretiskt perspektiv, ILM : Serie I:67, ISBN 1653-1523, National Defence College, Department of Leadership and Management, Karlstad, Sweden

Andrzejewski, S. (1954). Military Organisation and Society, Routledge \& Kegan Paul LTD, ISBN 65012010128, London, UK

Auf der Heide, E. (1989). Disaster Response: Principles of Preparation and Coordination, The C.V. Mosby Company, MO, ISBN -13 978-0801603853, St. Luois, USA

Ben-Ari, E. (2005), Epilogue: A "Good" Military Death, Armed Forces \& Society, Vol. 31, pp. 651-664

Cameron, K.S., Kim, M.U., \& Whettten, D.A. (1987). Organizational effects of decline and turbulence, Administrative Science Quarterly, Vol. 32, No. 2, pp. 222-240, ISSN 00018392

Drabek, T.E. (1983). Alternative patterns of decision-making in emergent disaster response networks, International Journal of Mass Emergencies and Disasters, Vol. 1, No. 1, pp. 277305, ISSN 00333352

Drabek, T.E. (1985). Managing the emergency response, Public Administration Review, Special Issue: Emergency Management: A Challenge for Public Administration, Vol. 45, pp. 8592, ISSN 1940-2006

Drabek, T.E., \& McEntire, D.A. (2002). Emergent phenomena and multiorganisational coordination in disasters: lessons from the research literature, International Journal of Mass Emergencies and Disasters, Vol. 20, No. 2, pp. 197-224

Glaser, B., \& Strauss, A.L. (1967). The discovery of grounded theory: Strategies for qualitative research, Aldine, ISBN -13 978-0202302607, Chicago, USA 
Hochschild, A. (2003). The managed heart: Commercialization of human feeling, University of California Press, ISBN 0-520-23933-4, Berkeley, California

Kapucu, N. (2006), Interagency Communication Networks During Emergencies: Boundary Spanners in Multiagency Coordination, American Review of Public Administration, Vol 36, No. 2, pp. 207-225

Kendra, J.M., \& Wachtendorf, T. (2003). Creativity in Emergency Response after the World Trade Center Attack', in Beyond September 11th: An Account of Post-Disaster Research, Natural Hazards Research and Applications Information Center, Public Entity Risk Institute, and Institute for Civil Infrastructure Systems, Special Publication No. 39. Boulder, CO: Natural Hazards Research and Applications Information Center, University of Colorado, USA, pp. 121-146

Kendra, J.M., \& Wachtendorf, T. (2006). The Waterborne Evacuation of Lower Manhattan on September 11: A Case of Distributed Sensemaking, Preliminary paper \#355, Disaster Research Center, University of Delaware. USA, Available at http://dspace.udel.edu:8080/dspace/bitstream/handle/19716/3194/Preliminary\%20Paper $\% 20 \% 23355$.pdf?sequence $=1$

Kirschenbaum, A. (2004). Chaos organization and disaster management, Marcel Dekker, ISBN-13 9780824747152, New York, USA

Larsson, G., Harem, T., Sjöberg, M., Alvinius, A., \& Bakken, B. (2007). Indirect Leadership under Severe Stress: A qualitative Study through the Subordinates' Eyes: a qualitative inquiry of the 2004 Kosovo riots, International Journal of Organisational Analysis, Vol. 15, No 1, pp. 23-34

May, P.J. (1985). FEMA's role in emergency management: examining recent experience, Public Administration Review, Vol. 45, pp. 40-47

McEntire, D.A. (1998). Towards a Theory of Coordination: Umbrella Organizations and Disaster Relief, Quick Response Report No. 105, Natural Hazards Research and Information Application Center, University of Colorado, Boulder, Colorado, USA, Available at http://www.colorado.edu/hazards/research/qr/qr105.html

Mendonça, D., \& Wallace, W.A. (2004). Studying organisationally-situated improvisation in response to extreme events, International Journal of Mass Emergencies and Disasters, Vol. 22, No. 2, pp. 5-29

Morgan, G. (1986). Images of organization, Sage, Beverly Hills, California

SOU 2005:104, Swedish Government Official Report (2005). Sweden and the Tsunami: Examination and Proposals, Swedish Tsunami Commission, ISBN 91-38-22476-3, Stockholm, Sweden

Uhr, C., Johansson, H., \& Fredholm, L. (2008). Analysing emergency response systems', Journal of Contingencies and Crisis Management, Vol. 16, No. 2, pp. 80-90

Webb, A. (1991). Co-ordination: a problem in public sector management, Policy and Politics, Vol. 19, No. 4, pp. 229-241

Williams, P. (2002). The competent boundary spanner, Public Administration, Vol. 80, No. 1, pp. 103-124

http://www.who.int/hac/crises/international/asia_tsunami/en/ 